University of South Florida

DIGITAL COMMONS

Digital Commons @ University of

@ UNIVERSITY OF SOUTH FLORIDA

South Florida

Government and International Affairs Faculty

Publications

Government and International Affairs

1993

\title{
Democracy and Socialism in Sandinista Nicaragua
}

Gary Prevost

St. John's University/College of Saint Benedict, Gprevost@csbsju.edu

Harry E. Vanden

University of South Florida, vanden@usf.edu

Follow this and additional works at: https://digitalcommons.usf.edu/gia_facpub

Part of the Government Contracts Commons, and the International Relations Commons

\section{Scholar Commons Citation}

Prevost, Gary and Vanden, Harry E., "Democracy and Socialism in Sandinista Nicaragua" (1993).

Government and International Affairs Faculty Publications. 37.

https://digitalcommons.usf.edu/gia_facpub/37

This Book is brought to you for free and open access by the Government and International Affairs at Digital Commons @ University of South Florida. It has been accepted for inclusion in Government and International Affairs Faculty Publications by an authorized administrator of Digital Commons @ University of South Florida. For more information, please contact digitalcommons@usf.edu. 


\section{- Acknowledgments *}

Many individuals and organizations made this book possible. We are particularly indebted to Andrew Reding, senior fellow at the World Policy Institute in New York. Andrew was originally to be a coauthor, but other commitments made that level of participation impossible. We profited greatly from his comments and assistance in various stages of the project. Gary Prevost wishes to acknowledge the financial assistance of the Fulbright Program's Central American Republics Research Grant that supported his sabbatical research in Nicaragua in 1990-1991. He also wishes to acknowledge the Bush Foundation for support of an earlier research trip to Nicaragua. Harry Vanden gratefully acknowledges travel and field support grants from the Division of Sponsored Research and the College of Social Science of the University of South Florida. St. John's University and the Department of Government and International Affairs of the University of South Florida funded numerous trips to professional meetings where the authors presented various chapters of the book as panel papers and gained valuable feedback from fellow Nicaraguanists, particularly Thomas Walker of Ohio University. Valuable comments from John Britton, Lou Pérez, and Steve Watrous were helpful, as was the assistance of Gary Ruchwarger, Martha Morgan, and Rose Spalding.

In Nicaragua the authors are indebted to many individuals and institutions who facilitated their research. These individuals include Vanessa Castro, Patricia Elvir, Edgar Parrales, Ramón Menneses, Tomás Borge, Carlos Vilas, Sixto Ulloa, Rafaela Cerda, Francisco Campbell, Carlos Tünnerman, Miriam Hooker, Mariano Fiallos, Murielle Vigil, Julio Valle Castillo, Victor Tirado, and Alejandro Martínez Cuenca. Organizations that provided assistance include the Secretariat of the FSLN, the National Assembly, the Institute of Nicaraguan Studies (IEN), the Supreme Electoral Council (CSE), the Institute for the Development of Democracy (IPADE), the Nicaraguan Women's Association (AMNLAE), the International Relations Department of the FSLN, the Valdivieso Center, and 
the Foundation for the Global Economic Challenge (FIDEG). The Departments of Government at St. John's University and the University of South Florida provided material assistance to complete the work. Research assistants Tom Ricker, who made the index, and Linda Alegro were particularly helpful. Research assistants Garrett Chapman and Kevin Schooler prepared the bibliography. We especially wish to thank Shirley Zipoy at St. John's University for her office assistance and to acknowledge the support of Kate Watts and Lynne Rienner at Lynne Rienner Publishers. Both authors wish to acknowledge the support of their compañeras, Catherine Kocy and Vera Vanden.

Harry E. Vanden Gary Prevost 


\section{* ONE * \\ Introduction: On Democracy}

With the deepening of the struggle .... only the workers and the peasants will go all the way.

-Augusto César Sandino ${ }^{1}$

Do not be frightened into their surrender by the alarms of the timid, or the croakings of wealth against the ascendancy of the people.

-Thomas Jefferson ${ }^{2}$

When it took power in July 1979 , the Sandinista government of Nicaragua did not have any well-developed theory of Marxist democracy on which to draw. Nor did it have fully democratic Marxist models on which to base its praxis or on which it could rely for support, sustenance, and encouragement to develop its own democratic Marxism. There were few real-world examples and little support from actual nation states to develop a democratic form of socialism, and even fewer to do so within the specific historic conditions in Nicaragua. ${ }^{3}$ The absence of these factors made the construction of such a democratic socialism difficult. It also retarded the development of sufficient confidence to sustain truly unique democratic institutions in the face of increasing external pressure from the United States and decreasing support from the Eastern European countries.

Both the United States and the Soviet Union thought their respective model was the best for the Nicaraguans. Even though the Soviets were more subtle, both superpowers were to some degree uncomfortable with a uniquely Nicaraguan road to development and democracy that would break radically from the Eastern and Western models. Ironically, each side believed that developments in Nicaragua were wholly inadequate and indicative of either dominance by Western influences (from the perspective of the socialist East) or communism (from the perspective of the capitalist West). The socialist states were, however, clearly more willing to support Nicaragua because the ideology was nominally Marxist (even 
though the economic and political systems were very different from those in Eastern Europe). The socialist states also realized that Nicaragua's newly found independent, nonaligned stance threatened the traditional hegemony that the United States had exercised in the Caribbean Basin. ${ }^{4}$

The popular insurrection that swept the Sandinistas to power in 1979 initially endowed the emerging political system with a strong participatory dimension. It did not, however, coincide well with either Western representative democracy or Eastern bureaucratic socialism, since both of these systems had either diminished or never adequately evolved mechanisms to insure or facilitate direct, ongoing participation by the people.

The Marxist tradition is more diverse than the now-failed socialist states in Eastern Europe would suggest. As with Jeffersonian democracy, theoretical Marxism allows for real or direct democracy as well as nonparticipatory forms of governance that claim to be participatory. The first relies more heavily on innovative theoretical interpretations, while the second is based on Leninist conceptualizations of the party and actual socialist practice.

Before Stalinism poisoned the international socialist movement, Marxism was not a fixed dogma; it was a means of understanding events and a theoretical guide for developing all aspects of socialism. ${ }^{5}$ Among these were ways of assuring that democracy developed under socialism (see Megill 1970, p. 54). In his now widely quoted essay, "What is Orthodox Marxism?" (originally published in the early 1920s), Georg Lukacs $(1971$, p. 1) argues that Marxism "does not imply the uncritical acceptance of the results of Marx's investigations. It is not the 'belief' in this or that thesis, not the exegesis of a 'sacred' book. On the contrary, orthodox refers exclusively to method."

Thus Marxism can and should be developed in light of new and different conditions. The Russian Marxist dissident Roy Medvedev (1975, p. $\mathrm{xx}$ ) argues that "Marxism, in my view, is not some kind of dogma but a science that should be developed and enriched by new ideas and theories, while propositions that prove to be obsolete, one-sided, or even wrong must be discarded." And as to democracy, he is even more specific: "It is absolutely not true that Marxism and socialism are incompatible with democracy." He does note that "the works of neither Marx and Engels nor Lenin adequately deal with the complex problems involved [with democracy]" (ibid.), and calls for the development of democratic Marxist theory to fill this gap. Lamentably, this task has not yet been accomplished.

As Marxists like Lukacs strove to assert their independence and develop democratic theory and practice in Hungary in 1956 (Lukacs was minister of education in the short-lived Nagy government and was imprisoned and exiled for his involvement), they were brutally crushed by the Soviet juggernaut that had been fashioned by Joseph Stalin. Even 
more to the point, the vibrant, experimental, and very democratic Marxism (socialism with a human face) that was led by Alexander Dubcek in the Prague Spring of 1968 was also crushed by Soviet tanks before any of the theoretical or practical problems of democratizing Marxism could be resolved. A similar fate seems to have met many others who attempted to democratize Marxist theory or practice. For instance, when Rudolf Bahro (1978, esp. part 3) wrote his now famous work Die Alternative in 1977 and called for an emancipatory alternative to the bureaucratic socialism that had developed in Eastern Europe, he was first forced from the party in the German Democratic Republic and then forced into exile. The generally negative reception that such calls for a democratic, participatory alternative in Eastern Europe received made it difficult for creative Marxist thinkers everywhere and further retarded the development of democratic Marxist theory.

No form of democracy has been easy to achieve in the Latin American context. Although most Latin American nations have been republics for some 170 years (Brazil was an empire until 1889 and Cuba did not gain its independence until 1902), few have been able to achieve any consistent democracy and many have been influenced as much by outside forces as by the will of their own people. Nicaragua, for instance, experienced long periods of dictatorial rule, the frequent intervention of the Marines, and the seizure of power in the 1850 s by a Yankee mercenary, William Walker, who declared himself president and designated English as the official language. Like most of Latin America, its history, institutions, and political culture were heavily imbued with authoritarianism and often influenced by some of the least democratic aspects of its large neighbor to the North.

If the first, nineteenth-century (bourgeois democratic) revolutions did not firmly root nominal Western democracy in all of Latin America, many hoped that the second (socialist) revolutions would break the authoritarian tradition and interject vibrant forms of people's democracy into the political milieu. Indeed, Fidel Castro and Ché Guevara dreamt of a continental revolution that would forge free and independent socialist republics in which the people could rule their destinies. But their dream has been difficult to realize. First, other socialist revolutions were not immediately triumphant. Second, as Cuba gained more autonomy and freedom as an independent nation, the constant economic and political pressure from the United States combined with other factors to prevent it from transcending its authoritarian political culture or setting aside the antidemocratic influences from Eastern Europe. Cuba did not begin to hold elections or provide other forms of democratic participation for more than a decade after the revolutionary triumph. Reforms in the mid-1970s did, however, institutionalize regularized local elections and initiate a 
series of new structures and procedures (popular power in particular) that facilitated greater participation and decisionmaking power for the Cuban masses, though mostly at the lower level (see Harnecker 1980). These reforms and the participation they engendered represented a new and different attempt to keep alive the democratic ideal in Latin Americathis time in a state that was well along the path of socialist construction. Michael Lowy (1986, p. 270) observed that "popular power in Cuba represents a real democratic advance in the transition to socialism and an example that should be carefully studied." But like its Eastern European counterparts, Cuba was still struggling with authoritarian and bureaucratic party rule. Nor did the constant pressure from the United States diminish the perceived need for an authoritarian state. The popular power movement did interject an element of democracy at the local level. Decisionmaking at the national level, however, was still far removed from direct control by the people. No national leaders were elected directly by the people or by their mass organizations.

This reality and the growing bureaucratization of Cuban society led many to wonder if the construction of socialist states in Latin America would actually enhance the practice of democracy. The triumph of progressive forces in Chile in 1970 suggested that even more traditional forms of Western-style democracy might allow some Latin American nations with more firmly established democratic political cultures and institutions to use these to construct socialism and stimulate even greater participation by the popular masses. The flowering of democracy and socialism during the Allende years proved inspirational for many Latin Americans. In the eyes of many, Chile even began to serve as a model of democratic socialism in Latin America. However, the bloody 1973 coup and the Pinochet dictatorship that followed suggested that Western democracy and socialism might not be compatible at all and that more authoritarian measures might be necessary to ensure the continuation of socialism and even the possibility of more expansive democracy at a later time.

The triumph of the Sandinista revolution in Nicaragua in July 1979 established a state that valued its freedom and independence highly. The Sandinista revolution was clearly under the hegemony of a Marxist vanguard party, but it was also dedicated to the democratic incorporation of the Nicaraguan people and-because of the broad-based, multiclass composition of the coalition of forces that toppled Anastasio Somoza-to democratic pluralism. Although buffeted by the residual effects of the revolution against Somoza and the increasing hostility of the United States after 1981, there was (in varying degrees) a commitment to building both democracy and socialism in the new state.

The case of Nicaragua thus posed an important question: can a Latin American - or Third World - nation, struggling to achieve a larger degree 
of freedom and independence, sustain relatively high degrees of both democracy and socialism? And more specifically, can democracy exist within a state that is based on a nationalist variant of Third World Marxism? Even some writers who are sympathetic to the socialist enterprise are ready to acknowledge the difficulty of achieving democracy in this context. Orlando Núñez Soto and Roger Burbach (1986, p. 106) admit that the "majority of socialist countries ... have not been ideal political or cultural democracies." They note that such regimes have been plagued by authoritarianism, vertical bureaucratic tendencies, and elitist behavior (ibid.). Recently, even some Soviet writers - enlivened no doubt by perestroika-suggested that the reason Joseph Stalin was able to impose an absolute authoritarianism on the Soviet nation so easily was that the original Bolshevik Party contained centralized tendencies that facilitated this process (see Keller 1988). One writer went so far as to suggest that "the sternest indictment of state socialism is its stifling of grass-roots initiative" (ibid.). Writing from a critical perspective, Medvedev (1981, esp. chap. 2) suggested that such tendencies may even be inherent in some, though not all, of Lenin's thought. Further, and perhaps more precisely, the initial variant of Latin American Marxism that was championed by the Comintern and eventually adopted by virtually all the orthodox Marxist parties in Latin America was that of a rather traditional Soviet authoritarian conception of socialism that left little room for democratic initiative of any kind (see NACLA 1987, Caballero 1987, Vanden 1986). It emphasized the centralization of power and the key and unchallenged role of the vanguard party. The advocates of this position were hesitant to concede too much power to the people themselves and were thus less than trusting of peasant-led revolutionary movements or populism generally (see Vanden 1986, Hodges 1986).

In Latin America there were a few early Marxist innovators like José Carlos Mariátegui (Peru, 1894-1930), but they had not been successful in breaking away the Latin American Marxist movement from Sovietcentric (if not Stalin-dominated) dogmatic authoritarianism. Half a century later Carlos Fonseca Amador and the other Sandinista leaders were finally able to enjoy a great deal more success in a very different historical period. Formulating theory and praxis in a small peripheral society in the 1960 s, 1970 s, and 1980s, a second generation of Sandinista leaders broke with this past (and the orthodox Nicaraguan Socialist Party) to develop a different kind of Marxism - one that was much less constrained and could take full advantage not only of polycentrism and Eurocommunism, but of the democratic, participatory dimension of the New Left in the West, the experiment with socialist democracy in Chile, and the popular power movement in Cuba. The historic reality in which the construction of socialism in Nicaragua occurred was thus radically different from that of 
other Third World nations.

Unlike the stolid, bureaucratized state socialism that Stalin and his followers had developed in the Soviet Union and Eastern Europe, that which was developing in Nicaragua was much more in touch with the democratic, popular dimension of Marxism. As such, it offered many new possibilities. Founding Sandinista National Liberation Front (FSLN) members Carlos Fonseca Amador and Tomás Borge had brief, problematic associations with the pro-Soviet, Nicaraguan Socialist Party but had not stayed with the party because they believed its (Stalinist) version of Marxism was not a viable example of how Marxism should be developed in Nicaragua. When Borge was exiled in Peru, Fonseca Amador told him to seek out Esteban Pavletich. The Peruvian had served as Augusto César Sandino's secretary and had been the primary link between Sandino's struggle and the iconoclastic group of Peruvian Marxist-Leninists led by Mariátegui. In talking with Pavletich about Mariátegui, Borge was utilizing one of the few sources of authentic Latin Marxism and symbolically laying the groundwork for the development of a non-Stalinist Marxism in Nicaragua. Indeed, Borge's view of Mariátegui (who was eventually condemned by the Soviets in the 1930s) was that "he was the most important Marxist that Latin America produced." Conversely, he was openly critical of other Latin American Marxists who had dogmatically followed the Soviet line. ${ }^{6}$ The Sandinistas hoped to break with the old authoritarian Marxism that had dominated the movement in and outside of Latin America. To do so they realized that they must infuse their ideology and politics with a strong dose of popular democracy. However, it was not always easy to decide just which forms of democracy were optimal or applicable.

\section{Capitalist and Socialist Conceptions of Democracy}

"Democracy" derives from demos, the people, and kratos, the exercise of power. In its original sense it means power of the people (Medvedev 1975, p. 31). American academic Samuel Huntington $(1989$, p. 12) suggests that "democracy can be defined in terms of who rules, for what ends and by what means." In its most radical sense, it is, as Abraham Lincoln said, a government of the people, and by the people, and for the people. Unlike other types of government, it claims to allow the people themselves to rule, to make the decisions that govern their lives, and "all reasonable people, when they speak of democracy, mean a system in which collective decisions, i.e., the decisions which affect the whole community, are taken by all interested parties" (Bobbio 1976, p. 111). They are to decide their own destiny through their participation in the political process. 
Although democracy in the abstract has few detractors, there is no unanimity of opinion on exactly which forms of political participation are essential for democracy or precisely which political institutions best allow the demos to have a say in the governmental process. Richard Fagen (1986, p. 258) believes that there must be effective participation by individuals and groups in the decisions that most affect their lives, a system of accountability such that leaders and officials can be monitored and changed if necessary, and political equality so that all have an equal opportunity to participate in the political process.

Upon closer examination, one finds not one, but several visions of democracy. These include representative democracy as practiced in Western nations, people's democracy as practiced in many MarxistLeninist states, and direct or participatory democracy as practiced by young students and workers in Paris in 1968 and by the people of Prague in the spring of 1968 . There is also growing interest in grass-roots democracy, especially as manifest in the worker self-management and neighborhood control movements. But as different types of democracy proliferate, agreement on what is essential to democracy is more difficult to achieve. Thus, groups that hold one form particularly dear are often loath to admit that other forms might also tap other dimensions of democracy.

In North America and Western Europe some have been very skeptical of the kind or degree of democracy allowed by governmental structures that are not identical to their own. Thus many believed that Nicaragua, because it was guided by a party that considered itself socialist, could not possibly harbor democracy (see U.S. Dept. of State 1987). Socialists have been equally critical of Western-style representative democracy. Lenin (1971,pp. 295-296), for instance, argued that the real essence of bourgeois parliamentarianism was "to decide once every few years which member of the ruling class is to repress and crush the people through parliament." Accordingly, he and many Marxists believed that elections and formal parliamentary institutions did not guarantee democracy either. Rather, they believed such formal institutions must be transformed into working bodies-like Marx's original vision of the Paris Commune of 1871 or the original local soviets in 1917-that allowed the people to have a direct say in the making of policy (ibid., pp. 296-297; see also Marx 1960, 1978).

As we examine what democracy means, it may be possible to find some similarities in the ways in which democracy is conceived and practiced in socialist and capitalist states. Like John Locke, Marx did not like government and planted the idea - which Lenin developed - that the state apparatus should disappear ("wither away" in Lenin's words). Like Jefferson, he saw government as a necessary evil to be endured only in a transitional stage of socialism while the material bases of class differentiation were eliminated. As the polity moved to a more advanced stage of 
socialism (communism) it would no longer be necessary to have a government, and the people would rule directly. Indeed, he thought he saw the seeds of such rule when he observed the popular assemblies in the Paris Commune in 1871.

Both Marx and Jefferson trusted the people and thought that they would rule wisely and justly under the right conditions. Neither thought that rule should be far removed from the people, and both believed the interests and opinion of the majority should be the final arbiter. Although their modern-day disciples have often found themselves in opposition, Marx and Jefferson shared a similar view of human nature and democracy, if not government as well. Like the French thinker Jean-Jacques Rousseau, both men saw an inherent goodness in all human beings. This led them to place their faith in the people and their inherent ability to control their affairs. They did not think that others should be forever ordained to govern for them. Responding to Rousseau's introductory remarks in The Social Contract, that while born free people are everywhere in chains, Marx ends the Communist Manifesto with his now-famous observation that the proletariat has a world to win and nothing to lose but its chains. Nor did Jefferson-who thought rebellion every twenty years or so was salutary to the body politic-believe that the freedom of the people should be usurped by an elite. ${ }^{8}$ As he put it shortly before he died in the summer of 1826 , "the light of science has already laid open to every view the palpable truth that the mass of mankind has not been born with saddles on their backs, nor a favored few booted and spurred ready to ride them ..." (in Padover 1956, p. 344).

Jefferson hated monarchy and aristocracy and believed in the people: "My most earnest wish is to see the republican element of popular control pushed to the maximum of its practicable exercise." Only then could government be "pure and perpetual." The writer of the Declaration of Independence thought government should be minimal and always under the control of the people. Although he accepted representative government (as contrasted to direct rule by the people) as a necessity, because he believed it was not possible to have direct government in entities that were much larger than New England townships, he thought that such governing should be by the citizens "acting directly and personally, according to rules established by the majority." Further, the degree of rule by the people should be judged in proportion to the "direct action of its citizens," and the next best thing to pure democracy is where people in branches of government "are chosen by the people more or less directly" (in Padover 1939, p. 39).

At one point Jefferson went so far as to propose a ward system for Virginia, wherein everyone could be "an acting member of the common government, transacting in person a great portion of its rights and duties" 
(in Lobel 1988, p. 824). In that tradition, many nineteenth-century American radicals rejected the whole system of representative government and argued that laws should be passed by referendum. They believed that the population should participate directly in the governmental decisionmaking process (ibid.).

The origins of this pure view of democracy extend back through Rousseau to classical Greece where it was assumed that all qualified individuals would not only vote but would directly engage in government through selection by lot or through voluntary participation. Initially, however, the enfranchised demos was a very select group comprised of men who were large landowners or had other means of wealth that allowed them the time to pursue the affairs of state (all women, slaves, and those of lesser means were excluded). When democracy was reborn and developed after the American Revolution, the categories and numbers of those so enfranchised were gradually widened. As European systems were reformed to include more political participants, the idea of some type of rule by the people gained legitimacy and wider acceptance. Gradually its forms (though not necessarily its radical essence) spread to more distant parts of Europe and Latin America in the nineteenth century. By the second half of the twentieth century, the concept of participation in elections and other democratic enterprises by virtually all the citizens was widely accepted.

Classical or orthodox theories of democracy are strongly premised on real popular participation in the governmental process. Commitment to this theory of democracy therefore implies a belief in the desirability and necessity of widespread popular participation. Likewise, the corollary is that low levels of political interest and participation result from inadequacies in the structures or opportunities for participation that exist in a particular polity and not from any inherent inadequacies in the people themselves (see Osbun 1985, p. 29). Classical democratic thinkers like Rousseau (as well as Jefferson) are therefore seen as theorists par excellence of participation as an integral part of democracy. They also hold that equality and economic independence are the minimum conditions necessary for such democratic participation. For thinkers like Rousseau and John Stuart Mill, "participation has far wider functions and is central to the establishment and maintenance of the democratic polity" (Pateman 1970, p. 20).

This vision of democracy runs through American history and was manifest in populist leaders like Andrew Jackson and in populist movements. It also can be seen in the widening of the voting franchise and in the institutionalization of and recourse to initiative, referendum, and recall that blossomed in the late nineteenth and early twentieth centuries (see Goodwyn 1976, Salvatore 1982, Hahn 1983). In his work on direct 
democracy, Thomas Cronin (1989, pp. 19-20) finds that these reform movements gradually opened up the American political system to allow more direct democracy and that such manifestations "have been a lasting and generally positive part of the American landscape" (p. 2). Recent manifestations include the calls for direct democracy by students in the 1960 s and the current movements in favor of grass-roots, neighborhood, and workplace democracy. Although not as prevalent as Jefferson might have hoped, democracy based on widespread popular participation has its advocates and supporters (see, for instance, Bachrach and Baratz 1962 and Bachrach 1967). It is still practiced in the New England town meeting and in isolated areas like the Swiss Canton of Apenzell, where the local populace meet around an ancient tree once a year to decide what will be done in the twelve months that follow (Woodstock 1971, pp. 12-13).

But there is another strain of democracy that emerged in the West. In the United States, the writers of The Federalist Papers did not think that direct participation of the mass of the people in government was always possible or desirable. Rather they believed that the people should be represented by those who understood the true needs of the republic (those with wealth and/or position). James Madison did not even think that representatives had to be tied directly to the interests of the electorate (Lobel 1988, pp. 828-829).

When arguing for strengthening the federal government, Alexander Hamilton (The Federalist Papers, Federalist 35, 1952) is even more clear: "The actual representation of all classes of the people by persons of each class, is altogether visionary." Hamilton further assumed a commonality of interest between all those who labored in a particular sector of society regardless of their particular wealth. To his way of thinking, the poorest tenant and wealthiest landlord had a common interest (Lobel 1988, pp. 828-829). As suggested elsewhere in The Federalist Papers, there have been those who did not think direct democracy was necessary and further believed that chosen representatives (who might come from the wellheeled) could represent the interests of all. Democracy was thus equated with representative government. And after 1787-1788, many held that "democracy meant not government by and of the people, but simply representative government" (ibid., p. 830).

On the other hand, there was considerable concern that the new, more centralized constitutional structure of the United States government would remove power from the hands of the people. The Federalist Papers were in large part written to calm such popular fears. The author of Federalist 57 (The Federalist Papers 1952, pp. 176-179) spends a considerable amount of time answering the charge that the leadership of this new government "will be taken from that class of citizens which will have least sympathy with the mass of the people, and be most likely to 
aim at an ambitious sacrifice of the many to the aggrandizement of the few." Federalist 55 (The Federalist Papers 1952, p. 172) also attempts to refute the charge that the House of Representatives "will be taken from the class of citizens which will sympathize least with the feelings of the masses of the people, and be most likely to aim at a permanent elevation of the few on the depression of the many." John Adams wanted forms of government that stressed avoiding the excesses of pure or direct democracy (Cronin 1989, p. 15). The constitutional structure provided the framework for a system of indirect democracy and minimized the tradition of direct democracy that was as old as the English settlements in North America (ibid., p. 1). Popular concerns about such exclusionary visions of democracy did not, however, stop the constitutional structure from being implemented in 1789. This set in motion an emphasis on indirect forms of democracy and a deemphasis on popular participation. Over time this has evolved into a system where there is less and less popular participation.

In a current version of Hamilton's thinking, George Will argued that the "people are not supposed to govern; they are not supposed to decide issues. They are supposed to decide who will decide" (in ibid., p. 21). But even participation in elections (deciding who will decide) is declining. In recent local elections in the United States, an average of fewer than 20 percent of those registered voted. In the presidential election of 1984, only 53 percent of the eligible voters participated. In the 1988 election the figure was reduced to 50 percent, meaning that some 26 percent of the eligible electorate in the United States chose the president. Only 36 percent of the electorate voted in the 1990 midterm election. This evolution has prompted many writers to be critical of what is currently termed democracy in the United States and to suggest that it is far from majoritarian rule (Parenti 1983).

In his recent article "America as a Model for the World? A Skeptical View," Ted Robert Gurr (1991, p. 665) notes that "empowered political minorities can block concerted action" on major policy issues such as medical care and social services for those in need. In America: What Went Wrong? Donald Barlett and James B. Steele (1992, p. ix) note how the concentration of wealth and power has derailed American democracy. They observe that the "wage and salary structure of American business, encouraged by federal tax policies, is pushing the nation toward a twoclass society. The top 4 percent make as much as the bottom half of U.S. workers." Such trends at least suggest that some care should be taken in holding up this form of democracy as a perfect model that should be emulated at all cost by developing nations like Nicaragua. Indeed Greider (1992) finds that American democracy has been betrayed.

Revisions of classical democracy have found their theorists in more modern times. In his well-known work Capitalism, Socialism and Democ- 
racy, Joseph Schumpter (1943, p. 283) argues that the "electoral mass is incapable of action other than stampede." Similarly, he believes participation no longer has a central role in the democratic process (see Pateman 1970 , p. 5). Another revisionist theorist even suggested that limited participation and apathy have a positive function because they cushion the shock of disagreement, adjustment, and change. ${ }^{10}$

These writers were expressing unease with that manifestation of the beliefs of the masses that Rousseau (1952, esp. book 2) termed the popular will (volonté populaire), which is sometimes equated with unreflective or unenlightened public opinion. It is assumed that there is also a general will (volonté général) that represents a (more enlightened and) more informed common interest. "The general will alone can direct the State according to the object for which it was instituted, i.e., the common good" (ibid., p. 395). And, "what makes the will general is less the number of votes than the common interest among them" (ibid., p. 397). The democratic revisionists believed that different forms of indirect, representative democracy could express the interest of the people (represent their general interest) as well as or better than direct democracy. But there is more to Rousseau's thinking. He stipulates that the will is only general if it is the will of the entire body of the people, while it is not when it is only the will of a part of it. And further, "there is often a great deal of difference between the will of all and the general will; the latter considers only the common interest, while the former takes private interest into account, and it is no more than a sum of particular wills ..." (ibid., p. 396). Thus many of the democratic revisionists assume that a class of representatives may be able to ascertain the general will for the people even though the government itself may not precisely be of the people. That is, a group not of the people can decide for the people.

The idea of a small group deciding for the many is not limited to revisionist theorists of Western democracy. This concept has perhaps its most perfect articulation in Lenin's conception of the vanguard party as that entity that best understands the needs of the majority (the working class in the modern, increasingly industrialized world) and is therefore most competent to implement policy that benefits it. The theoretical underpinning of the Leninist party is premised on the assumption that the vanguard can know the general will of the people. With the revisionist thinkers in the West, little attempt is made to distinguish between a general will that-no matter how hard to know-considers only the common interest and a will of all that is no more than a sum of particular wills (ibid.).

One is here reminded of the work of Robert Dahl, one of the most prominent current revisionist theorists of democracy. Dahl (1956, p. 143) found that as long as there are representatives of each group involved in 
the decisionmaking process in some (not necessarily effective) way, representative democracy is alive and well: "In American politics, as in all other societies, control over decisions is unevenly distributed; neither individuals nor groups are political equals. . . . Thus the making of governmental decisions is not a majestic march of great majorities united upon certain matters of basic policy. It is the steady appeasement of relatively small groups" (ibid., p. 164). In Dahl's original conceptualization of democracy (polyarchy), the rule of multiple minorities was presented as a model of what works in the American political system (and what is therefore desirable). ${ }^{11}$ Under Dahl's system, all the people were not involved in the decisionmaking process, only some of their representatives were consulted on some issues. This is a far cry from the classical vision of democracy that sees all of the demos participating in the vital decisionmaking processes of government. Yet this view has been widely accepted as an accurate description of representative democracy in the United States and (implicitly) as a model for democratic government. In such systems, participation has no central role. All that is necessary is that enough citizens participate to keep the electoral machinery working (Pateman 1970, p. 5). ${ }^{12}$

This commonly accepted view of democracy in the West is problematic. First, it contradicts the clear participatory dimension of democracy found in classical Greece and in Rousseau's and Jefferson's writings; second, it assumes that educating the masses for their central role in the decisionmaking process is not necessary or important. Writers from Rousseau to John Dewey have underscored the importance of education, informed deliberation, and participation in the democratic process and hold them essential to the effective functioning of democracy. L. Davis $(1964$, pp. 40-41) underscores the importance of these processes and argues that participation has an ambitious purpose:

the education of the entire people to the point where their intellectual, emotional, and moral capabilities have reached their full potential and they are joined freely and actively in a genuine community....

Systems that do not achieve such education, popular deliberation, and involvement do not, we believe, realize their full potential and therefore could be considered singularly ill-suited as models of democratic government. The bureaucratized socialism of Eastern Europe-though it did provide education - afforded little popular deliberation and less meaningful participation. In the United States, there is much popular deliberation, but the quality of education often diminishes its effectiveness. Over the past few decades, there has been less and less participation in most forms of governance, while economic and political power has become 
more and more concentrated. Gurr $(1991$, p. 666$)$ has noted that policymaking in the United States has not made for the most egalitarian of societies: ${ }^{13}$

Between 1977 and 1988 the after-tax income of the poorest fifth dropped $10 \%$, of the next poorest fifth, it dropped $3 \%$. At the other end of the scale the household income of the richest fifth increased $34 \%$. And for the top one percent it increased $122 \%$.

Barlett and Steele (1992, esp. chap. 9) suggest that the political process in the United States is increasingly responding more to wealth and influence than popular need or participation. According to federal statistics released in early 1992, the top 1 percent of households in the United States had greater net worth than the bottom 90 percent of households by 1989 (New York Tïmes 1992, p. 1).

In contrast to the concentration of wealth and influence and declining participation in the United States, classical or full democracy considers participation essential. Moreover, democracy that is participatory is founded on two complementary notions: "that people are inherently capable of understanding their problems and expressing themselves about these problems and their solutions" and that "real solutions to problems require the fullest participation of the people in these solutions, with the development of freedom from dependency on authorities and experts" (Oppenheimer 1971, p. 277). The idea is to create a polity in which everyone will participate to the fullest in decisions that concern their everyday or long-range affairs. The process of decisionmaking, therefore, is as important as the actual immediate decision made.

Thus one is led to ask the more difficult questions of if and where adequate models of full democracy exist. As he explored this question along the way to the formulation of a new democratic theory, Megill (1970, p. 44) observed that, in different ways, the liberal democrats in the West and the Stalinists in Eastern Europe have each "diverted democracy from its basic tradition of rule by the people." In the socialist countries, the people have been replaced by the party, which is in turn controlled by the party organization (ibid.). Leninist and therefore Communist views of democracy flow from the model of the Marxist-Leninist Party that developed in Russia and the relation of the party to the society. This party was successful in seizing power, but it failed as an instrument for the thoroughgoing democratization of society, particularly as it developed under Stalin's rule (ibid., p. 43). This is ironic because, from his earliest writings, "Marx was committed to the idea of direct democracy. His early conception of such democracy involved a Rousseauesque critique of the principles of representation..." and he held the view that "true democracy 
involves the disappearance of the state and thus the separation of the state from civil society" (Bottomore et al. 1983, p. 114).

Marx was greatly inspired by the Paris Commune of 1871 , which took the management of the revolution into its hands. In it, "plain working men [and women] for the first time dared to infringe upon the Governmental privilege of their 'natural superiors' [in Jefferson's terms, those who thought themselves born "booted and spurred" to ride the masses] and, under circumstances of unexamined difficulty, performed their work modestly, conscientiously, and efficiently ..." (in Marx 1978, p. 636).

In Marx's mind, the Commune - which was more advanced than the communes that developed in the Middle Ages and was in part inspired by the first French Commune of 1792 (which Jefferson championed) - was the first glimpse of how democracy might work in a socialist society. It was formed by municipal councillors who were chosen by universal suffrage in each ward and were "responsible and revokable at short terms." The majority were working people or their acknowledged representatives. The Commune itself was to be "a working, not a parliamentary body, executive and legislative at the same time" (ibid., p. 632). And (ibid., p. 633)

In a rough sketch of national organization which the Commune had no time to develop, it states clearly that the Commune was to be the political form of even the smallest hamlet, and that in the rural districts the standing army was to be replaced by a national militia, with an extremely short term of service. The rural communes of every district were to administer their common affairs by an assembly of delegates in the central town, and these district assemblies were again to send deputies to the National Delegation in Paris, each delegate to be at any time revocable and bound by the mandat impératif (formal instructions) of his constituents. The few but important functions which still would remain for a central government ... were to be discharged by Communal, and therefore strictly responsible agents. The unity of the nation was not to be broken, but, on the contrary, to be organized by the Communal Constitution....

The people would decide most issues directly at the commune level and would send their direct, recallable representatives to provincial and national assemblies that would in turn decide those issues that could not be handled at the local level. The legitimate functions of government were to be restored to the responsible agents of society, the common people. This system would be very different from old representative institutions, where every three or six years it was decided "which member of the ruling class was to misrepresent the people in Parliament" (ibid.). Lest there be any misunderstanding, Marx explicitly states that "nothing could be more foreign to the spirit of the Commune than to supersede universal suffrage by hierarchical investiture" (ibid.). Throughout history there have been a 
few other examples of direct communal rule, starting with the original Christian communities and including the communes formed in Republican Spain by the socialists and anarchists during the Spanish Civil War. The kibbutzim in Israel are perhaps the most widely known and successful example (Woodstock 1971, p. 21).

In socialist thought, democracy is thus conceived as popular democracy in which-as with Rousseau and Jefferson-the majority rules. According to the Marxist conception of democracy, majority rule means rule by the poorer classes (in those societies that have not yet achieved advanced socialism) since they are by definition the majority (see Kiss 1982 , chaps. 1,2). Some analysts go on to say that democracy is class determined and thus does not exist if the popular classes (where there are still classes) do not rule (ibid., pp. 11-12). But others, who followed Lenin's ideas and were influenced by Stalin, did not see democracy as an end in itself. It was a means of achieving social emancipation. Like the socialist revolution, it was a means of achieving liberation (ibid., p. 122). The revolution was to break down the machinery of class domination and allow a dictatorship of the proletariat to rule for the working people while the structure of the new society was developing. Such a class dictatorship was only considered necessary until the old bourgeois state could be replaced by the classless society, at which time the people would rule directly as the state withered away.

According to Lenin, the vanguard party was to lead the people in the socialist revolution and guide the state while the new society was being constructed. But Lenin's ideas very much flowed from the Russian political culture that produced his thought. Hannah Arendt (1958) notes, for instance, that the revolution occurred in a country with a well-established centralized bureaucracy. Russia had a very authoritarian culture, and "it stands to reason that if any aspect of social life can directly affect government it is the experience with authority that men [and women] have" $(\mathrm{H}$. Eckstein as cited in Pateman 1970, p. 12). The historic conditions in which the first experiment in socialist rule developed influenced not only Soviet Marxism, but - because of the influence of the Soviet Union - the way in which socialist thought and praxis developed elsewhere. Commenting on the relative lack of democracy in the Soviet Union and Eastern Europe, Mihailo Markovic (1982, pp. 171-173) also notes that the political culture included elements of "Byzantine-Oriental societies" that did little to instill the libertarian values that foster democracy. Rather they added to the authoritarian influences that imprinted the development of Marxism.

The first days of the Russian revolution were exciting and dynamic. Workers' councils or soviets took control of neighborhoods and factories in St. Petersburg, much the same way the people had formed communes in Paris during the first days of the French Revolution of 1792 and the 
Paris Commune of 1871 . Democracy was alive, direct, and vibrant. The people themselves were exerting their rule. As the revolution raged on and foreign powers cut off the infant socialist state economically and sent expeditionary forces to overthrow it, conditions were considered to be such that more authoritarian measures were needed. Democracy became restricted as the people ruled less and less directly. Lenin, however, believed that democracy could be reinstituted after the revolution was no longer threatened (Medvedev 1975, p. 43). He held that if "during the transition period from capitalism to socialism there are some restrictions on democracy (and the extent of these restrictions must be gradually reduced), nonetheless with the full victory of socialism all restrictions on political democracy fall away" (in ibid., p. 31). Indeed, Lenin said, "The victory of socialism is impossible without the realization of democracy" (ibid.).

But for Lenin the structure and the vanguard role of the party were fundamental. In the 1920 s there was considerable discussion of how the party would be organized and exactly what relation it would have to the exercise of power by other segments of the society. Before he died in 1924 , Lenin had already begun to express concern about the role of bureaucracy. In this context, the question of party organization was central, but by then what had come to be called democratic centralism had been accepted. Ironically, although designed to democratize the functioning of the party, in reality it did not allow any real discussion of the issues or contact with the revolutionary movement as manifest in the toiling masses (Megill 1970, p. 43).

After Lenin's death there was even less opportunity for discussion. As Stalin consolidated his power, he came to view any opposition as a hostile bourgeois influence that had to be resisted (Medvedev 1975, p. 44). Thus not only was popular democracy discouraged, but dissent was not tolerated. The heady democracy of the first days of the revolution was increasingly replaced by bureaucratic authoritarian party rule. The Left opposition tried to resist these trends inside the Soviet Union. They were not successful and, like Leon Trotsky, many were killed.

Although many other socialists objected to Stalinism, they did not object to the "paternalistic justification of systematic antidemocratic measures of some form" (Cunningham 1987, p. 274). Lenin believed that the Communist Party was best equipped to know the general will of the people and rule on their behalf. Stalin evidently came to believe that he was best suited to decide important issues in the party. Thus a party bureaucracy that was increasingly dominated by one person began to rule in the name of the people. These decisions were ostensibly made to safeguard if not save the revolution from its internal and external enemies. Practical necessity was cited as the rationale. In theoretical terms, it was argued that 
certain tactical decisions were necessary but that their implementation and effect were temporal. Megill (1970, p. 62) holds that the effects were much more far-reaching: they led to a theoretical failure of Stalinism that in turn crippled the democratic Marxist tradition because it failed to "distinguish between purely tactical considerations - practical considerations, which may be more or less correct at a given moment-and the theoretical development of Marxism."

The Hungarian Marxist Georg Lukacs is equally clear on this issue: "In other words: instead of following the true method of Marxism and developing a strategy and tactics from an analysis of events, tactical decisions - right or wrong decisions - were decisive, and a theory was built on these" (cited in ibid., p. 62). Lukacs further argues (ibid., p. 55) that

The tremendous historical guilt of Stalinism exists in the fact that not only was scientific development not followed up, but this development went backwards. Stalin hindered just those tendencies which would have been capable of developing Marxism.

As Marxist theory and practice developed in the Soviet Union and those areas of the world that were modeled after it, its democratic and participatory dimensions were generally neglected if not directly subordinated to immediate concerns as defined by the party leadership. In the West, representative democratic institutions became bulwarks against direct and majority participation in government, which in turn laid the basis for the transformation of these institutions into paternalistic organs of minority rule (Cunningham 1987, p. 276). In socialist countries similar processes occurred (ibid., p. 356). The paternalistic vanguardism of the party was substituted for the direct rule of the people that Marx glimpsed in the Paris Commune. Although party congresses and even elections were held in the peoples' democracies, the demos was ruled much more than it ruled. Milovan Djilas $(1957,1962)$ has suggested that a "new class" of rulers had developed in such societies and that they had usurped popular rule. The state did not wither away and democracy did not develop. Stalin even argued that the state must be strengthened greatly before it could wither away (Bottomore et al. 1983, p. 463). Elaborate rationalizations attempted to show how the people were actually being served because the party was deciding on their behalf by setting the agenda and limiting the number of candidates for whom the people voted in elections. ${ }^{14}$ As had been done by Dahl and other revisionist theorists of democracy in the West, theory was elaborated to explain how (some) democracy actually did exist in the status quo, even though that reality was lacking when it came to real democracy and democratization. In both instances, it seemed it was much easier to change, modify, or reinterpret the theory than it was to change the status quo and actually allow the people to have power. 
Many who wrote from a Marxist perspective did not realize that there was a confluence of interests and perspective on the part of the hierarchies of both Eastern socialism and Western capitalist democracy. They were both heavily invested in the status quo and reluctant to allow any change. As with the bureaucratization of the state and party in Eastern Europe, several scholars have noted that there has been an historical proliferation of bureaucracy and bureaucratic thought in U.S. institutions. Decisions and initiatives for problem solving have come more and more from the center, thus discouraging local participation (see, inter alia, Wiebe 1967, Higgs 1987, and Lasch 1979, 1991). The elite in Eastern Europe criticized the economic and political marginalization of the majority in capitalist democracy but would not institute genuinely democratic institutions at home. The establishment in the West would criticize the elitist rule in socialist states while allowing economic and political elites to exercise increasingly more power at home and the masses to participate less and less. Neither moved to increase democracy. Both argued that the people were better off in their respective system and insisted theirs was the model to copy.

Despite the poverty of democratic examples in both the capitalist West and socialist East, Nicaragua had set about the process of constructing real democracy within a socialist state. The Sandinista revolution had rediscovered Nicaragua's popular history and thus its popular consciousness; it had indeed unleashed the power of the masses. Unlike other revolutionary experiences, there was enough understanding among the Sandinistas, members of the popular church, Nicaraguan and internationalist youth, and others involved with the revolutionary process to set up institutional structures that included and channeled mass participation. The masses had not only been mobilized, they had found ways they could continue to express their will. But the reality was complex. On the one hand the Sandinista leadership was delighted to see "the people" (which was how they conceived the diverse, multiclass popular revolutionary force in Nicaragua) fully mobilized. On the other hand they feared that if they immediately held elections, the formal Western facade of institutional democracy that Somoza and many other traditional Central American leaders had manipulated to foreclose real and effective participation might well be the only democracy that would be allowed to develop. The Sandinista leaders were also well acquainted with Leninist thinking as to the vanguard role of the party and thus felt they had a special obligation to prepare the people by ensuring that their political consciousness was developed. The dominant role the party had assumed in the decisionmaking process in Cuba also helped to incline their thinking in more authoritarian directions. Because they also feared the influence of bourgeois elements inside the country, and in part because they could not totally break away from unconscious authoritarian beliefs (which resulted 
principally from Nicaraguan political history and culture), the Sandinista leadership, as principally manifested in the National Directorate, reserved a substantial amount of power to itself.

In the early 1980 s, the creation of Western representative institutions was postponed and direct participation was encouraged. But an authoritarian decisionmaking trend was developing inside the party and among those Sandinista leaders who held key governmental posts. These tendencies and the increasing military and economic pressure exerted by the United States worked against the further empowerment of the demos through direct and continued participation. Nor were traditional models of democracy in Eastern Europe or the West helpful in this regard. Subsequent chapters will show how these factors interacted to produce a unique development of democracy within a socialist state. Like the mixed economy in which it developed, both representative and participatory democracy eventually operated side by side under the guidance of the democratic centralism of the FSLN. Indeed, it seems that there was continued competition among Western representative democracy, participatory democracy, and democratic centralism. It remains to be seen if the confluence of these factors actually caused democracy to flower in Sandinista Nicaragua, or if it stifled the construction of what might have been the first full-blown example of direct, participatory Marxist democracy.

\section{Notes}

1. Augusto César Sandino in El pensamiento vivo, Vol. 2 (1984, p. 72).

2. Thomas Jefferson in Padover (1939, p. 34).

3. The problem of existing models of socialism is explored in Lowy (1991).

4 . Thus, the socialist states were willing to continue to support Nicaragua not only because they hoped it would eventually become more like their own systems, but because the Sandinistas proved to be a thorn in the side of U.S. hegemony, much the same as Yugoslavia (which was a founder of the Nonaligned Movement) had been for the USSR and the hegemony it exercised in Eastern Europe.

5. By the late 1920s, after V. I. Lenin's death in 1924, Joseph Stalin (18791953) consolidated his rule in the Soviet Union. By the early 1930 s he emerged as the unchallenged Soviet leader. His increasingly dictatorial rule thwarted any attempts at democracy in the USSR. He continued in power until his death in 1953, his authoritarian version of Marxism continued to haunt the Soviet regime and those patterned after it in Eastern Europe and elsewhere. See Bottomore et al. (1983, pp. 460-464) and Deutscher (1949).

6. Vanden interview with Tomás Borge, Managua, December 7, 1984. 7. For an establishment understanding of democracy, see the opening edi-
torial, "Why the Journal of Democracy," by Diamond and Plattner (1990, pp. 3-5). The journal was funded and established by the National Endowment for Democ-
racy. 
This definition includes peaceful competition for all effective positions in government through elections, independent political participation, and a high level of civil and political liberty as necessary conditions for democracy. It does not seem to require that all the people be involved (directly or indirectly) in the actual governmental process, or that decisions in government be representative of majority interests or even majority opinion. Some might even observe, cynically, that such a definition could classify as democratic a system in which the majority of those eligible to vote do not vote for their national leaders and in which many decisions seem increasingly to favor the interests of the wealthy and powerful over the poor and powerless: that is, a system that appears to have a representative democratic form but lacks actual democratic content and is no longer run by or for the majority of the people.

8. Writing to Madison in 1787, Jefferson observed: "I hold it, that a little rebellion, now and then, is a good thing, and as necessary in the political world as storms in the physical" (in Padover 1939, p. 19). Writing to William Smith that same year: "God forbid we should ever be twenty years without such a rebellion" (ibid., p. 20).

9. It should be noted, however, that in Switzerland the franchise was limited to males until 1971 and that this decision was resisted in Apenzell. Apenzell is a relic of one of the few successful peasant revolts (1408) in which the masses were able to rid themselves of their overlords.

10. Pateman's (1970, p. 7) assessment of B. R. Berelson.

11. In "Two Faces of Power" (1962), Bachrach and Baratz demonstrated how this form of democracy does not even include each group's representatives in the agenda-setting process and may only consult them on nonessential issues. See also Bachrach (1967).

12. Given the continual low voter turnout through the 1980 s in the United States, it remains to be seen if even this minimalist definition of democracy has been met. See William Greider, Who Will Tell the People: The Betrayal of American Democracy (1992).

13. Interestingly, Gurr does not address the decline in electoral participation; nor do other authors in the special section of PS, "America as a Model for the World" (December 1991).

14. Ironically, Bachrach and Baratz argue that the elite in the United States uses similar tactics by limiting the range of choices that people actually have. See Bachrach and Baratz (1962, pp. 947-952). 